\title{
Metropoliten Kent Yönetimine Geçiş: Türkiye ve İtalya Örnekleri
}

\author{
Transformation to the Metropolitan Urban Government: Turkey and Italy Cases
}

\section{Bayram COȘKUN}

Prof. Dr., Muğla Sıtkı Koçman Üniversitesi,

IİF, Kamu Yönetimi Bölümü,

bcoskun@gmail.com

https://orcid.org/0000-0002-6803-7534

\section{Çiğdem PANK}

Arş. Gör., Muğla Sitkı Koçman Üniversitesi, İ̈F, Kamu Yönetimi Bölümü,

cigdem-zeynep@hotmail.com

https://orcid.org/0000-0002-7084-313X

\section{Eyüp ŞEN}

Arş. Gör., Muğla Sitkı Koçman Üniversitesi, İ̈F, Kamu Yönetimi Bölümü,

eyupsen@mu.edu.tr

https://orcid.org/0000-0002-5045-8345
Makale Başvuru Tarihi: 18.08.2019

Makale Kabul Tarihi: 10.09.2019

Makale Türü: Araştırma Makalesi

\begin{abstract}
ÖZET
Anahtar

Kelimeler:

Yerel Yönetim,

Büyükşehir

Belediyesi,

Metropoliten Kent Yönetimi,

Italya,

Hızlı nüfus artışı ve kırdan kente göçün ivme kazanması, Türkiye'de metropoliten kentlerin ortaya çıkmasına yol açmıştır. Metropoliten kentlerin kendilerine özgü sorunlarlarıyla başedebilmek için farklı bir yaklaşımla yeni bir yapı oluşturmak bir ihtiyaç olarak ortaya çıkmıştır. Bu ihtiyaca cevap verebilmek için 1982 Anayasası'nın 127. maddesine "kanun, büyük yerleşim merkezleri için özel yönetim biçimleri getirebilir" hükmü konulmuştur. Bu anayasal izinden sonra 1984 yılında Türkiye'de metropol alan niteliğini kazanmış üç büyük kentte ayrı bir yasal düzenleme ile "büyükşehir belediyeleri" oluşturulmuştur. Zaman içerisinde bu sayı 16 olmuştur. 2004 yılında da büyüş̧ehir belediyesi kanunu yenilenmiştir. 2012 yılında 6360 sayll Kanun ile büyükşehir belediye modeli önemli değişikliklere uğramış ve sayıları 30'a çıkmıştır. Metropoliten alan niteliğini kazanmış kentler için Avrupa ülkelerinde de yerel yönetim statüsünde iki kademeli veya geleneksel yapının dışında yeni bir formda idari teşkilatların oluşturulduğu görülmektedir. Bu kapsamda İtalya'da da metropoliten kent yönetimlerinin oluşturulduğu bilinmektedir. Bu çalışmada öncelikle Türkiye'deki büyükşehir belediye yapısı ana hatlarılyla tanttılacak, ardından Italyan yerel yönetim sistemi üzerinde durulacaktır. İtalyan yerel yönetim sistemi tanttıldıktan sonra, Türkiye'deki büyükşehir belediyeleri ile Italya'daki metropoliten kent yönetimleri; görevler, örgütsel yapl, mali kaynalar, görev ve sorumluluklar açısından karşılaştırılacak ve analiz edilecektir.
\end{abstract}

Keywords:

Local Government,

Metropolitan

Municipality,

Metropolitan Urban

Governance,

Italy,

\section{ABSTRACT}

Rapid population growth and the acceleration of rural-urban migration has led to the emergence of metropolitan cities in Turkey. It has emerged as a need to create a new structure with a different approach in order to be able to cope with the specific problems of metropolitan cities. In order to respond to this need, Article 127 of the 1982 Constitution stipulated that "the law can bring about special forms of government for large settlement centers". In 1984, after the permit of the constitution "metropolitan municipalities" have been established in three major metropolitan cities with separate legal arrangements. Over time, this number became 16. In 2004, the Metropolitan Municipality Law was renewed. In 2012, with the Law No. 6360, the metropolitan municipal model underwent significant changes and the number increased to 30. In European countries, it appears that administrative structures were organized in new forms in the local governments, apart from the two-tier or traditional structure. In this context, it is known that metropolitan city governments are formed in Italy. In this study, the metropolitan municipality system of Turkey will be introduced, then the focus will be on Italian local government system. After the introduction of Italian local government system, the metropolitan municipalities in Turkey and the Italian metropolitan urban governments will be compared and analyzed by giving references to the tasks, organizational structure, financial resources, duties, and responsibilities.

1 Bu çalışma 1-3 Kasım 2018 tarihinde Alanya'da (Antalya) düzenlenen Alanya Uluslararası Yerel Yönetimler Sempozyumunda sunulan "Türkiye'de ve İtalya'da Metropoliten Kent Yönetimi: Karşılaştırmalı Bir Analiz" adlı bildirinin gözden geçirilmiş ve değiştirilmiş halidir. 


\section{GIRISS}

Metropol kentlerin oluşması süreci 19. yüzyılda başlamış ve 20. yüzyılda hızlanmıştır. Metropol kentlerin kökeninde, 19. yüzyılda baş gösteren muazzam nüfus büyümesi vardır ${ }^{1}$. 1800'de Batı dünyasında hiçbir kent 1.000.000'luk nüfusa sahip değilken, 1900'e gelindiğinde, Berlin, Chicago, New York, Moskova, Tokyo gibi kentler dahil olmak üzere 1.000.000'dan fazla nüfusa sahip on bir metropol ortaya çıkmıştır (Mumford, 2013:640). Türkiye'de ise 1927 yılında nüfus 13.648.270 kişi iken, 2010 yllında 72.561.312'ye ulaşmıştır. Cumhuriyet dönemindeki ilk ve son sayımlar arasında geçen 80 yıllık süre içerisinde, ülke nüfusu \%531,7 oranında büyümüştür. Ülkelerin dünya nüfusu içerisindeki payı itibariyle yapılan sıralamada Türkiye 1950 yılında 21. sıradayken, 2010 yılında 18. sıraya yükselmiştir. Türkiye'nin artan nüfusu, özellikle 1950 sonrasında kentsel alanlarda toplanmaya başlamıştır. Bu da kentsel alanlarda nüfus yoğunlaşmasını arttırmış, 2010 yılına gelindiğinde yaklaşık her 4 kişiden üçü kentsel alanlarda yaşamaya başlamıştır (Demir ve Çabuk, 2010:194). Bu hızlı kentleşme süreci, Türkiye'de metropol kentlerin oluşmasına ve sayıca artmasına da neden olmuştur.

Avrupa ülkeleri başta olmak üzere birçok bölgede kent mekanlarının hızla büyümesi, bilgi ve teknoloji alanında ortaya çıkan gelişmeler, refah devletinin krizleri ve küreselleşme yerel yönetimler alanında metropoliten yönetim ve yönetişim tartışmalarını kaçınılmaz hale getirmiştir (Lefèvre, 1998:9). Bunun yanında geriye dönülmez şekilde büyüyen kentler giderek ihtisaslaşma gerektiren bir alan yönetimine dönüşmektedir (Toprak, 2014:314).

Dünya'da nüfusun metropol kentlerde toplanması, bu yerleşimlerde siyasi, idari, mekânsal, teknik, sosyal ve ekonomik bakımdan diğer yerleşimlere göre farklı boyuttaki karmaşık problemleri de beraberinde getirmektedir. Bu konudaki genel yaklaşım, büyük ölçekli şehirlerin nitelikleri gereği farklı bir kategoride değerlendirilerek, karşılaşılan çok yönlü problemlerin bu şehirlere özgü yaklaşım ve yapılarla çözülmeye çalışılması biçimindedir (Oktay, 2016:54).

Tarihsel açıdan bakıldığında, metropol kentlerin sorunlarını çözmek için başlatılan çalışmaların 19. Yüzyıl başlarına kadar gittiği görülmektedir (Eke, 1982:13). 20. Yüzyılın başında, daha 1920'lerde, büyükşehir reformu teorisi, yüksek oranda kentleşmiş alanların bölünmesinin, mevcut mülki-idari teşkilatın değiştirilerek belirli bir büyükşehir yönetim kurumunun kurulması ile aşılması gerektiğini savunuyordu (Swianiewicz ve Lackowska-Madurowicz, 2012:4).

Türkiye'de bu tartışmalar 1960 ve 70'li yıllarda ortaya çıkmış, ancak tartışmaların somut bir sonuç doğurması 1980'den sonra olmuştur. 1980'li y1llarda önce Anayasa ile yerel yönetim statüsünde metropol kent yönetiminin zemini oluşturulmuştur. Daha sonrasında da yapılan yasal düzenleme ile 1984 yılında Türkiye'de ilk defa 3 metropol kentte "büyükşehir belediyesi" kurulmuştur. Başlangıçta İstanbul, Ankara ve İzmir'de kurulan büyükşehir belediyelerinin sayısı, gerek Türkiye'deki diğer bazı kentlerin de süreç içerisinde metropol kent niteliğini kazanması gerekse de siyasi, ekonomik vb. faktörlerin etkisiyle giderek artmış ve 2010 yılına gelindiğinde 16'ya çıkmıştır. Bu zaman zarfında 2004 yılında büyükşehir belediyelerine ilişkin Kanun da yenilenmiştir.

2012 yılında ise, 2004 yılında yürürlüğe giren 5126 sayılı Büyükşehir Belediyesi Kanunu'nda ve ilgili diğer kanunlarda değişiklik öngören 6360 sayılı Kanun kabul edilmiş, bu yolla Türkiye'deki büyükşehir belediye sistemi köklü bir değişikliğe uğramıştır. Aynı düzenleme ile Türkiye'deki büyükşehir belediyelerinin sayısı 30'a çıkmıştır. Bu çalışmalar ile temel amaç, dünyada olduğu gibi Türkiye'de de metropol kentlerin etkin ve verimli yönetilmesi için etkili yerel yönetim modelini oluşturmaktır.

İtalya'da metropol kentler için ihtiyaca uygun idari yapı oluşturma arayışları 1950 yıllarına dayanmaktadır. Ancak bu konudaki somut gelişme 1990 yılında yaşanmış ve metropoliten kent yönetimine ilişkin yasal düzenleme yapılmıştır. O dönemde oluşturulan yapı İtalya'nın kendine özgü sebeplerinden dolayı hayata geçirilememiştir. Daha sonra metropoliten kent yönetimlerinin 2001 yılında bir yerel yönetim birimi olarak anayasaya konulması, bu idarelerin statüsünü güçlendirmiştir. Ancak uygulamada yaşanılan sorunların giderilmesi 2014 tarihli yasa ile mümkün olmuştur. 2014 tarihli yasa İtalya'da 10 metropoliten kent yönetimi oluşturmuştur.

1 Dünya nüfusu M.S. 1. y1lda 200 milyon iken, 1000 yılında ancak 310 milyona ulaşmış, 1800 y1lında 978 milyon ile bir milyar sınırına dayanmıştır. Yüz yıl sonra Dünya nüfusu 1900 yılında 1.650 milyon kişi olmuştur. Böylece 1000 yıl içinde gerçekleşmeyen artışın yüz yıl içinde gerçekleştiği görülmektedir (Yılmaz, 2013:43). Sonraki yıllarda Dünya nüfusunun iki katına çıkma süresi daha da kısalmış, 1900 sonrasında önce 50 yıla daha sonrasında 40 yıla düşmüştür. 1800'lerde 1 milyara yaklaşan Dünya nüfusunun bir tahmine göre \% 3’ü, diğer bir tahmine göre ise \% 8-10 arası kentlerde yaşamaktaydı (Hout, 2000:13). 
Bu çalı̧̧manın amacı Türkiye ve İtalya'da ortaya çıkan metropol kent yönetimi sistemini anlamak ve bu iki modeli ana hatlarıyla karşılaştırmalı olarak analiz etmektir. Bu amaç doğrultusunda ilk olarak Türkiye daha sonra İtalya'daki metropol kent yönetimi sistemi tanıtılacaktır. Sonrasında bu sistemler görev ve sorumluluklar, örgütsel yapı, mali kaynaklar, bağlamında değerlendirilecektir.

\section{TÜRKIYYE'DE BÜYÜKȘEHIIR BELEDIYYLLERİNIN KURULMASI}

Osmanlı döneminde 1855 y1lında İstanbul'da ilk belediyenin kurulması ile toplum yerel yönetim diye adlandırılan yeni bir idari yapı ile tanışmıştır. Osmanlı Devleti döneminde 50 yılı aşkın bir süre bu yeni idari birimin bütün vilayetlerde yaygınlaştırılması ve işler hale getirilmesi çalışmaları yürütülmüştür. 1876 tarihli Kanunu Esasi'nin 112. maddesi ile belediyelerin anayasal kuruluş haline getirilmesi yerel yönetimler açısından önemli bir dönüm noktası olmuştur. Kanunu Esasi'nin yürürlüğe girmesinden sonra Meclisi Umumi'nin 1877 y1lında kabul ettiği "Vilayât Belediye Kanunu" ile belediyeler kendilerine özgü bir yasal zemine kavuşmuştur.

Cumhuriyetin ilanından sonra kabul edilen 1924 Anayasası doğrudan belediyelere ilişkin bir hüküm içermemiştir ${ }^{3}$. Ancak geçen 70 yılı aşkın bir süre içerinde bir yerel yönetim birimi olarak belediyelerin toplum tarafından benimsendiği anlaşılmaktadır. Bu nedenle belediyeleri yeniden yapılandırarak güçlendirme yoluna gidilmiş ve bu amaçla 1930 yılında 1580 sayılı Belediye Kanunu çıkarılmıştır.

Kanunda belediye; "beldenin ve belde sakinlerinin mahalli mahiyette müşterek ve medeni ihtiyaçlarını tanzim ve tesviye ile mükellef hükmi bir şahsiyet" olarak tanımlanmıştır. 1580 sayılı Belediye kanunu farklı nüfusa ya da hizmet alanlarına sahip belediyeler için ayrıca bir sınıflandırma yapmamış aksine tüm belediyeler için aynı görev ve sorumlulukları tek bir mevzuat içinde tanımlamıştır. Ancak Türkiye'de kentleşmenin artması ve nüfusu 500.000 'in üzerinde olan kentlerin sayılarının çoğalması ile, bütün belediyeler için öngörülen tek tip idari yapı ihtiyaca cevap veremez hale gelmiş ve yeni arayışlara neden olmuştur. Bu kapsamda özellikle üç büyük kentte iki düzeyli bir yerel yönetim sistemi kurma fikri 1960'larda ortaya atılmış ve daha sonraki yıllarda da çeşitli çevrelerce desteklenmiştir (Eke, 1985:52).

Özellikle 1960 sonrasında yoğun bir biçimde Türkiye'nin gündemine gelen idari reform çalışmalarının bir parçası olarak yerel yönetim reformu hakkında da çalışmalar yürütülmüştür. 13.2.1962 gün ve 6/209 say1lı Bakanlar Kurulu Kararına dayalı olarak yürütülen ve merkezi idarenin yeniden düzenlenmesi esaslarının araştırılması amacını güden MEHTAP Projesi, merkezdeki kuruluşlar ile merkezî Hükümet Teşkilâtının, taşra birimleri ve mahalli idareler arasında görev dağılımı, mahalli idarelerin yetkileri, kaynakları, teşkilatlanması konularının ayrı bir proje olarak ele alınıp incelenmesi tavsiyesinde bulunmuştur (MEHTAP, 1966:365). MEHTAP'taki bu tavsiye neticesinde DPT ile TODAİE'nin işbirliği ile Prof. Fehmi Yavuz tarafından "Türk Mahalli İdarelerinin Yeniden Düzenlenmesi Üzerine Bir Araştırma" adlı çalışma raporu hazırlanmıştır.

Bu inceleme ve araştırmalardan ayrı olarak, 1967'de başlatılan ve 1971'de sonuçlandırılabilen İç-Düzen Projesi çerçevesinde mahalli idarelerin yeniden düzenlenmesi ile ilgili olarak İçişleri Bakanlığınca 12 adet kanun tasarısı hazırlanmıştır. Bu tasarılar, 1961 Anayasası'nın yerel yönetimlere ilişkin 116. maddesinin düzenlemelerine uygun olarak ve İç-Düzen araştırması sonuçlar doğrultusunda hazırlanmıştır. Bu tasarıların başlıcaları şunlardır:

- Belediye Kanunu Tasarısı,

- İl Özel İdaresi Kanun Tasarısı,

- Köy Kanunu Tasarısı,

- Metropoliten Hizmet Birliği Kanun Tasarısı ${ }^{4}$.

2 Aynı yılda başkent İstanbul için "Dersaadet Belediye Kanunu” çıkarılmıştır.

3 Ancak 1924 Anayasası tarafından şehir, kasaba ve köylerin tüzel kişiliklerinin tanınmasının belediyeye karşılık geldiği biçiminde yorumlar vardır (Meriç, 1983:31).

4 Bu çalışma neticesinde hazırlanan diğer kanun tasarıları şunlardır:

Belediye Cezaları Kanun Tasarısı, İş Yerlerinin Hafta Tatili, Öğle Dinlenmesi ve Açılıp Kapanma Saatleri Hakkında Kanun Tasarısı, Mahalli İdareler Enstitüsü Kanun Tasarısı, Mahalli İdareler Mali Denetleme Kurulu Kanun Tasarısı, Mahalli İdareler İktisadi Teşebbüsleri Hakkında Kanun Tasarısı, Mahalli İdareler Memurları Kanun Tasarısı. 
Yukarıda sayılan Metropoliten Hizmet Birliği Kanun Tasarısı İç-Düzen çalışmaların bir sonucu olarak ortaya çıkmış ve bazı değişikliklere uğradıktan sonra İstanbul Metropoliten Hizmet Birliği Kanun Tasarısı olarak 1976 yılı haziran ayı içinde Başbakanlığa sunulmuştur (DPT, 1977:165-167) ${ }^{5}$. Ancak tasarının kanunlaşması mümkün olmamıştır. 1979-1983 yıllarını kapsayan 4. Beş Yıllık Kalkınma Planı’nda da büyük kentler için yeni bir yaklaşım ile yönetim sorunlarının çözülmesi ve kent yönetiminin etkinliğinin artırılması yaklaşımı yer almaktadır .

12 Eylül 1980 tarihindeki askeri müdahaleden sonra büyük kentlerin sorunlarına yönelik çözüm arayışları devam etmiştir. Bu kapsamda büyük kentlerde özel bir yönetim sisteminin kurulması için ilk girişim büyük kentlerdeki küçük belediyelerin tüzel kişiliğinin kaldırılarak, buraların ilgili il belediyesine dahil edilmesi olmuştur ${ }^{7}$. Milli Güvenlik Konseyinin kararı doğrultusunda başta İstanbul, Ankara ve İzmir olmak Türkiye’nin muhtelif illerinde 147 belediye ve 176 köyün tüzel kişiliği kaldırılmıştır (Çınar vd., 2009:46). Bu uygulamayı büyükşehir yönetimi uygulamasına geçişte önemli bir adım olarak değerlendirmek mümkündür (Toprak, 2014:312).

34 numaralı kararın sıkıyönetim komutanlıklarınca farklı şekillerde uygulanması neticesinde, daha sistematik ve kapsamlı bir düzenlemeye ihtiyaç duyulmuş ve 1981 yılında 2561 sayılı Büyük Şehirlerin Yakın Çevresindeki Yerleşim Yerlerinin Anabelediyelere Bağlanmaları Hakkında Kanun çıkarılmıştır ${ }^{8}$. Bu Kanunun 1. maddesinde;

"enerji, içme ve kullanma suyu, kanalizasyon, ulaşım, toplu taşıma ve imar gibi temel belediye hizmetlerinin birbirleriyle uyumlu ve bütünleştirici bir planlama içinde yeterli ölçüde ve verimli bir biçimde yerine getirilmesini sağlamak amacıyla son genel nüfus sayımı sonuçlarına göre belediye nüfusu 300.000'i aşan büyük şehirlerin çevresinde bulunan belediye ve köyler, bu Kanunda belirtilen esas ve usullere göre yakınında bulundukları ana belediyelere bağlanabilir. Bu bağlantıda, bağlanacak belediye ve köylerin ana belediyelere uzaklıklart, ana belediyenin imkanları, hizmeti götürme ye birleştirme olanakları göz önünde tutulur",

biçiminde bir düzenleme yer almıştır. Böylece birleştirme işleminin belediye nüfusu 300.000'i aşan şehirler için öngörüldüğü anlaşılmaktadır.

Günlük sorunlara çözüm bulmak amacıyla atılan bu adımlar sonrasında metropoliten kentlerin sorunlarını çözmek üzere çalışmaların devam ettirildiği görülmektedir. Bu amaçla dönemin Milli Güvenlik Konseyi Genel Sekreterliği bünyesinde uzmanlardan oluşan bir komisyon oluşturulmuştur. Komisyon konuyu kapsamlı olarak ele almış, ancak çalışmalardan somut bir sonuç çıkmamıştır. Buna rağmen komisyonun çalışmaları daha sonra TODAİE tarafından yürütülen çalışmalara katkı sağlamıştır (Eke, 1985:52).

Bu çalışmalar yürütülürken, 1982 Anayasa'nın 127. maddesine 1961 Anayasasında yer almayan “Kanun, büyük yerleşim merkezleri için özel yönetim biçimleri getirebilir", hükmü konulmuştur? .

5 Bu tasarının uzunca bir hazırlık safhası olmuştur. 1968 yılında Bakanlar Kurulu Kararı ile Metropoliten nitelikteki şehirlerin idari yapısının ne olması gerektiği hakkında İçişleri Bakanlığı bünyesinde bir proje çalışmasına geçilmiştir. Bakanlıkça görevlendirilen elemanlar büyük şehirlerin ve şehir topluluklarının bulunduğu ülkelerde örgütlenmenin ne yolda olduğu hakkında teorik, hukukî ve uygulamaya dönük araştırmalar yapmışlar ve $\mathrm{Bu}$ çalışmalar sonunda 1970 yılında ortaya çeşitli raporlar konulmuştur (DPT, 1977:166).

6 4. Beş Yıllık Kalkınma Planındaki değerlendirme şu şekildedir:

"Türkiye'deki belediye sinırlarl içinde yaşayan nüfusun yarıdan çoğu, nüfusu 50 binin üstünde olan 48 kentte yaşamaktadır. Bu nüfusun hemen yarısı da üç büyük kentte (İstanbul, Ankara, İzmir) yoğunlaşmıştır. Toplam belediye nüfusunun dörtte birden azı da, nüfusu 10 binin altında kalan l 385 kasaba (ya da köyde) bulunmaktadır. Bu gelişmeler karşısında il yönetimi ve kentlerde yönetim çerçevesini belirleyen küçük üretici ilişsilerinden hareket eden, sinaileşme - kentleşme sürecinin gerisinde kalan ve yerel yönetimlerin merkezi yönetim karşısında güçsüzlüklerinin nedeni olan 1930'ların belediye modeli, işlevlerini göremez durumdadır. Ayrıca metropoliten alanlara özge bir yönetim biçimi ve altyapı organizasyonu gereksinmesi belirginleşmiş; etkin bir yönetime ve kaynak yaratıcl, tüketiciyi koruyan, kentin biçimlenmesinde söz sahibi bir belediye yapısına kavuşulamamıştır. Belediyelerin özerkliklerinin sağlanmasında, merkezi yönetime parasal bağımlılıkları, yeterli öz kaynaklardan yoksunluk, belediyelerin kararlar, eylem ve işlemleri, organlarl ve görevlileri üzerindeki vesayet yetkileri başlıca darboğazlar olma niteliğini korumuşlardır" (DPT, 1979:81-82).

7 Bu işlemin hukuki zeminini Milli Güvenlik Konseyi'nin 11 Aralık 1980 tarih ve 17187 sayılı Resmi Gazete'de yayımlanan 34 numaralı kararı oluşturmuştur. Bu karar şu şekildedir:

1. Ülkemizdeki hızlı nüfus artışı ve köyden kente göçün sonucu olarak büyük kentlerimizin yakınlarında teşekkül etmiş olan belediyeler; aydınlatma, su, kanalizasyon ve ulaştırma gibi hizmetlerin yeterli bir şekilde halka götürülememesine ve kontrolün aksamasına neden olmaktadır.

2. Büyük kentlerin çevresinde teşekkül etmiş olan bu durumdaki belediyelerin Sıkıyönetim Komutanlıklarının koordinesinde ve onların emredecekleri şekilde ana belediyelere bağlanması bir plan dahilinde ve en kısa zamanda sağlanacaktır.

88 Aralık 1981 tarih ve 17538 sayılı Resmi Gazete'de yayımlanmıştır. 
Anayasaya eklenen bu hüküm ile metropoliten kentler için oluşturulması düşünülen iki düzeyli yerel yönetim sisteminin anayasaya aykırılık sorunu da ortadan kalkmıştır. Yürütülen çalışmalar sonucunda 23 Mart 1984 tarihinde çıarılan 195 sayılı Kanun Hükmünde Kararname (KHK) ile Türkiye'nin üç büyük kentinde Büyükşehir Belediye sistemi kurulmuştur. Aynı yıl 3030 sayılı Büyük Şehir Belediyelerinin Yönetimi Hakkında Kanun Hükmünde Kararnamenin Değiştirilerek Kabulü Hakkanda Kanun TBMM'de kabul edilmiş, böylece KHK, kanuna dönüştürülmüştür ${ }^{10}$.

Bu kanun ile getirilen yeni sistemin temel özellikleri şöyle belirtilebilir (Eke, 1985:52, 3030 sayılı Kanun md. $6)$;

- Büyük kentlerde, iki düzeyli bir yerel yönetim sistemi meydana getirilmiștir. Alt düzeyde büyükşehir içindeki ilçeler ile merkez ilçede kurulan "ilçe belediyeleri", üst düzeyde ise bütün kenti kapsayan "büyü̈sşehir belediyesi” oluşturulmuştur.

- Büyükşehir belediyesi; yatırım planları ve programları, nazım plan, meydan, cadde ve ana yolların bakım ve onarımı, terminaller ve otoparklar gibi tesisler, çevre sağlığı, su kanalizasyon, gaz, merkezi 1sıtma, çöp ve sanayi atıklarının imha ve değerlendirilmesi, itfaiye gibi tüm anakenti ilgilendiren stratejik nitelikli hizmet ve konularda yetkili iken, ilçe belediyeleri ise burada sayılanların dışında kalan ve yürürlükteki mevzuatla belediyelere verilen bütün görevleri yürütmekle görevlendirilmişlerdir.

İlk etapta İstanbul, Ankara ve İzmir'de oluşturulan büyükşehir belediye yapısı zaman içinde yaygınlaşmıştır. 1986-1988 yılları arasında çıkarılan yasalarla sırasıyla Adana, Bursa, Gaziantep, Konya ve Kayseri büyükşehir belediyesi sistemine geçirilmiş ve 1988 yılında toplam büyükşehir belediyesi sayısı sekize ulaşmıştır.

1993 yılında çıkarılan 504 sayılı Yedi İlde Büyükşehir Belediyesi Kurulması Hakkında Kanun Hükmünde Kararname ile 8 olan büyükşehir belediyesi sayısı 15'e ulaşmış ve bu KHK ile Antalya, Diyarbakır, Eskişehir, Erzurum, Mersin, Kocaeli (İzmit) ve Samsun belediyeleri büyükşehir belediyesi statüsüne geçirilmiştir. 2000 yılında çıkarılan 593 sayılı Sakarya İlinde Büyükşehir Belediyesi Kurulması Hakkında Kanun Hükmünde Kararname ile Sakarya /Adapazarı 16. büyükş̧ehir belediyesi olarak kurulmuştur. 1993'den 2011 yılına kadar Sakarya istisnası hariç büyükşehir belediyesi kurma girişimleri sonuca ulaşamamış ve 2011 yılına kadar büyükşehir belediyesi sayısı 16 olarak kalmıştır.

2004 y1lında Avrupa Birliği'yle uyum çabalarının da etkisiyle başlatılan yerel yönetim reformu kapsamında, yaşanılan 20 yıllık tecrübe 1şığında ve ortaya çıkan yeni ihtiyaçlar doğrultusunda 3030 sayılı Kanun yerini 5216 sayılı Büyükşsehir Belediyesi Kanunu'na bırakmıştır. 5216 sayılı Büyükşsehir Belediyesi Kanunu, büyükşehir belediyelerinin sınırlarını genişletmiş ve İstanbul ve Kocaeli ilinde ilin sınırı ile büyükşehir belediyesinin sınırı eşitlemiştir. $\mathrm{Bu}$ düzenleme 2012 yllında hayata geçirilecek yeni büyükşehir belediyesi sisteminin pilot uygulaması olarak kabul edilebilir.

5216 sayılı Kanunla getirilen yeni sınır düzenlemesine göre, nüfusları doğrultusunda büyükşehir belediyelerin sınırları belli yarıçaplı daireler çerçevesinde genişletilmiştir. İstanbul ve Kocaeli Büyükşehir Belediyeleri hariç, diğer ondört büyükşehir belediyelerinden nüfusu 1.000.000'a kadar olanların sınırları $20 \mathrm{~km}$, nüfusu 1.000 .000 ile 2.000.000 arasında olanlar $30 \mathrm{~km}$, nüfusu 2.000.000'un üzerinde olanlar ise $50 \mathrm{~km}$ genişletilmiştir (Zengin, 2014:100). Daha sonraki dönemde 5216 sayılı Kanun'da ihtiyaç doğrultusunda bazı değişikliklerin yapıldığı görülmektedir. 5747 sayılı Büyükşehir Belediyesi Sinırları İçerisinde İlçe Kurulması ve Bazı Kanunlarda Değişiklik Yapılması Hakkında Kanun" ile büyükşehir belediye yapısı içinde yer alan "ilk kademe"12 belediyeleri kaldırılmış, yeni bir düzenleme ile bunlar ilçe belediyesine dönüştürülmüştür. 2004-2012 yılları arasında yapılan yasal düzenlemelerle büyükşehir belediyelerinin görev ve hizmet alanları genişletilmesiyle daha geniş coğrafi alanlara sahip daha güçlü bir büyükşehir belediye yönetimi oluşturulmuştur (Özgür ve Savaş Yavuzçehre, 2016:905).

12.11.2012 tarihinde kabul edilen 6360 sayılı On Dört İlde Büyükşehir Belediyesi ve Yirmi Yedi İlçe Kurulması İle Bazı Kanun ve Kanun Hükmünde Kararnamelerde Değişiklik Yapılmasına Dair Kanun ile Türkiye'deki

9 Eke (1985:52), 1961 Anayasası döneminde iki düzeyli bir yerel yönetim sistemi oluşturma çalışmalarının sonuca ulaşmamasının bir nedeni olarak Anayasaya ters düşme kaygısı olduğunu belirtir.

$10 \quad 09.07 .1984$ tarih ve 18454 sayılı Resmi Gazete'de yayımlanmıştır.

11 22.3.2008 tarih ve 26824 sayılı Mükerrer Resmi Gazete'de yayımlanmıştır.

12 İlk Kademe Belediyesi biçimindeki bir yapı, 3030 sayılı Kanunun ilk halinde yoktu. Ancak büyükşehir belediye sisteminin yaygınlaştırılması sırasında bazı il merkezi belediyelerinin sınırları içinde birden fazla ilçe bulunmadığı için, "ilk kademe belediyesi” formülü geliştirilmiş ve 504 sayılı KHK ile 3030 sayılı Kanuna yerleştirilmiştir. Görüldüğü gibi 2008 yılında tekrar başlangıçtaki sisteme dönülmüştür. 
büyükşehir belediye sistemi önemli değişikliklere uğratılmıştır. Bu kapsamda bir il belediyesinin büyükşehir belediyesine dönüştürülebilmesi için temel şart olan nüfus ölçütü değiştirilmiş, il nüfusunun 750.000 ve yukarısında olması biçimine dönüştürülmüştür. 6360 sayılı Kanun ile yeni ve farklı bir uygulama öngörülmüş, Türkiye'de var olan büyükşehir yönetim modeli, il bazlı büyükşehir yönetimine dönüştürülerek yaygınlaştırılmıştır (Gül ve Batman, 2013:32; Yılmaz ve Kaypak, 2019: 4). Bu Kanunla Aydın, Balıkesir, Denizli, Hatay, Malatya, Manisa, Kahramanmaraş, Mardin, Muğla, Tekirdă̆, Şanlıurfa, Trabzon, Van ve Ordu il belediyeleri büyükşehir belediyesine dönüştürülmüştür. Böylece büyükşehir belediyelerinin sayısı otuza çıkmıştır.

Bunun dışında 6360 sayılı Kanunun getirdiği başlıca yenilikler ve değişiklikler şunlardır:

- Büyükşsehir belediyelerinde ilin sınırları ile büyükşsehir belediyelerinin sınırları eşitlenmiştir.

- Büyükşehir belediye sistemi içindeki ilçe belediyelerinin sınırı da ilçenin sınırlarına eşitlenmiştir.

- Büyükşehir belediye sisteminin kurulduğu illerde il özel idarelerinin tüzel kişiliği kaldırılmış, yani varlıklarına son verilmiştir.

- Büyükşehir belediye sisteminin olduğu illerde köylerin tüzel kişiliği kaldırılmış, köyler bağlı olduğu ilçe belediyesinin mahallesine dönüştürülmüştür.

- Büyükşehir belediye sınırları içinde bucak teşkilatları kaldırılmıştır.

- Büyükşehir belediyelerinin sınırları içinde yeni ilçeler kurulmuştur.

- Büyükşehir belediyelerinin bulunduğu illerde ilin tanıtımı, kamu kurum ve kuruluşlarının yatırım ve hizmetlerinin etkin olarak yapılması, izlenmesi ve koordinasyonu, acil çağrı, afet ve acil yardım hizmetlerinin koordinasyonu ve yürütülmesi amacıyla Valiye bağlı olarak "Yatırım İzleme ve Koordinasyon Başkanlığı" kurulmuştur.

- Genel Bütçeden yerel yönetimlere verilen paylar yeniden düzenlenmiştir ${ }^{13}$.

- Büyükşehir belediyelerinin gelirleri için yeni bir düzenleme yapılmıştır ${ }^{14}$.

- İl Özel idarelerinde il encümenin yapısı değiştirilmiştir. Buna göre; İl encümeni valinin başkanlığında, genel sekreter ile il genel meclisinin her yıl kendi üyeleri arasından seçeceği üç üye ve valinin her yıl birim amirleri arasından seçeceği iki üyeden oluşturulmuştur.

- Belediye sınırları içindeki mahalleler için minimum 500 kişilik nüfus sınırı getirilmiştir.

6360 sayılı Kanunun birçok hükmü 2014 yılındaki yerel seçimlerle birlikte yürürlüğe girmiştir. Böylece yerel seçimler sonrası yeni büyükşehir belediye sistemi tam olarak hayata geçmiştir. Yeni sistemin olumlu yönlerinin ağır bastığı söylenebilir ${ }^{15}$. Ancak daha iyi bir değerlendirme yapabilmek için biraz daha zamana ihtiyaç vardır.

Kısa bir değerlendirme yapmak gerekirse; 6360 sayılı kanunun gerekçesine bakıldığında ilk olarak büyük ölçekli plan ve politikalara ve bunların uygulanmasına olan ihtiyaç vurgulanmıştır. Planlama ve koordinasyonun sağlanamayışı, ölçek ekonomisinden yeteri kadar yararlanılamaması sebebiyle ortaya çıkan kaynak israfı kanunun gerekçesinde reformu gerektiren problemler olarak ortaya konulmuştur. Optimal ölçekte hizmet üretecek güçlü yerel yönetimler hedefi ise kanunun gerekçesinde bu kanunun temel amacı olarak belirtilmiştir. $\mathrm{Bu}$ amaç doğrultusunda 2004 yılında İstanbul ve Kocaeli illerinde hayata geçirilen büyükşehir belediyesi sınırının il sınırı olarak belirlenmesi uygulaması tüm büyükşehir belediyeleri için uygulanmak üzere genişletilmiştir (İzci ve Turan, 2013:125).

6360 sayılı Kanun ile eskiye kıyasla büyükşsehir belediyeleri ve büyükşehir belediye sistemi içinde yer alan ilçe belediyelerinin sınırları oldukça genişlemiştir. Konya Büyükşehir Belediyesi gibi bazı belediyelerin coğrafi alanı bazı Avrupa ülkelerinin coğrafi alanından daha geniş hale gelmiştir. Bu olgu ile, büyükşehir belediye başkanının dayandığı demokratik meşruiyet temeli de daha da güçlenmiştir. Böylece il sınırı içinde yaşayan

13 Kanunun 25. maddesine göre; Genel Bütçe vergi gelirleri tahsilâtı toplamının yüzde 1,50'si büyükşehir dışındaki belediyelere, yüzde 4,50'si büyükşehirlerdeki ilçe belediyelerine ve yüzde 0,5 'i il özel idarelerine ayrılır.

14 Kanunun 25. maddesine göre; 6/6/2002 tarihli ve 4760 sayılı Özel Tüketim Vergisi Kanununa ekli (I) sayılı listede yer alan mallardan tahsil edilen özel tüketim vergisi hariç olmak üzere, büyükşehir belediye sınırları içinde yapılan genel bütçe vergi gelirleri tahsilâtı toplamının yüzde 6'sı ile genel bütçe vergi gelirleri tahsilâtı toplamı üzerinden büyükşehirlerdeki ilçe belediyelerine ayrılan payların yüzde 30’u büyükşehir belediye payı olarak ayrılır.

15 Yeni büyükşehir belediye sistemine yönelik bazı eleştiriler de dile getirilmiştir. Örnek olarak bkz: Gözler, 2013:37-82. 
herkesi temsil eden bir kişi (büyükşehir belediye başkanı) ortaya çıkmıştır. Daha önce ne Osmanlı Devleti döneminde ne de Cumhuriyet sonrasında böyle bir durum söz konusu olmamıştır.

\section{3. İTALYAN YEREL YÖNETIM SISTEMI VE METROPOLITEN KENT YÖNETIMİ}

İtalya 1800'lerin sonralarında ulusal birliğini sağlamış ve Fransa örnek alınarak idari örgütlenmesini oluşturmuştur. Birinci ve ikinci dünya savaşları arasında çeyrek asır faşist diktatörlükle yönetilen ülke 1948 yılında yürürlüğe giren Anayasa ile Cumhuriyet rejimiyle yönetilmeye başlanmıştır. 1948 anayasası İtalya'da üniter parlamenter sistemi yönetim biçimi olarak uygulamaya koymuştur (Geray, 1997:53).

İtalyan Anayasası her ne kadar ülkeyi tek ve bölünmez, üniter bir devlet olarak tanımlasa da yerel özerklikler Anayasa tarafından tanınmaktadır. İtalyan Anayasası kamu hizmetlerinin yerine getirilmesinde yerinden yönetim ilkelerinin uygulanmasını öngörür. Anayasa, kamu hizmetlerinin yerine getirilmesinde önemli görev biçtiği yerel yönetim organlarını ayrıntılı olarak tanımlamaktadır (Toksöz vd., 2009:92). Bu durum da İtalyan Anayasası'nın yerel yönetim organlarına verdiği önemi ispat eder niteliktedir.

1948 Anayasasının 114. maddesine göre "Cumhuriyet bölgelere, illere ve komünlere ayrllır. Komünler, iller, metropol kentler ve bölgeler Anayasada belirlenen ilkelere göre, kendilerine özgü tüzük, yetki ve sorumluluklar olan özerk kuruluşlardır. ${ }^{\prime \prime 6}$. İtalyan Anayasa'sında başlangıçta yerel yönetim birimi olarak bölge ${ }^{17}$ - il - komün biçiminde bir yapı tanımlamıştır. Klasik yerel ve merkezi yönetim sistemlerinin değişen kent mekânının ihtiyaçlarına cevap verememesi ve ülkenin içinde bulunduğu politik atmosfer, dünyanın geri kalanına benzer bir şekilde İtalya'da da yerel yönetim sistemi üzerinde reform tartışmalarını gündeme getirmiştir. Bu tartışmalar sonucunda 1990 yılında metropoliten kentler yukarıda belirtilen üç birime ek olarak İtalyan yerel yönetim sistemine dâhil edilmeye çalışılmıştır. Metropoliten kent yönetimlerinin, büyük kentsel yerleşim yerlerinde il yerel yönetimlerinin yerini alması öngörülmüştür (Tortop, 1996:66).

Metropol alanları yönetmek için yeni idari yapı oluşturma arayışları ve düşüncesi İtalya'da 1950'lere kadar gitmektedir. Ancak İtalyan yerel yönetim sistemine ilk defa 1990 yılında çıkarılan 142/1990 sayılı yasa ile metropoliten kent yönetimi dâhil edilmiştir. Fakat metropoliten kent yönetimi kurulmasını öngören 142/1990 sayılı yasanın uygulanmasında bazı zorluklar ortaya çıkmıştır. $\mathrm{Bu}$ zorlukların bir nedeni, bölgelerin isteksizliğidir. Oluşturulan yapıda bölgelerin, metropoliten kent alanının sınırlarını belirlemesi ve metropoliten kentleri denetlemesi istenmiştir. Ancak, bölgeler siyasi arenada güçlü birer rakip haline gelebilecek olan bu yeni ve güçlü siyasi kuruluşların ortaya çıkışını desteklemek istememiştir (Swianiewicz ve Lackowska-Madurowicz, 2012:4).

1999 yılında çıkarılan 265/1999 sayılı yasa ile metropoliten kentleri kurmak için tekrar çaba gösterilmiş ancak bu çabalar da başarıyla sonuçlanmamıştır. 1990 yılında çıkarılan yasa, metropol kentler tam olarak tanımlanamadığı için yetersiz kalırken 1999 yılında çıkarılan yasa ise bölgesel sınırların belirlenmesini çok esnek bıraktığ 1 için pratikte metropoliten kentlerin kurulması mümkün olmamıştır. Nihayet 2001 yılında yapılan anayasa değişikliğiyle birlikte metropoliten kentler yukarıda belirtilen üç birime ek olarak İtalyan yerel yönetim sistemine tam olarak eklemlenmiştir (Boggero, 2016:3). Ancak bu anayasa değişikliği bile metropoliten kentlerin pratikte kurulmasını mümkün kılmamıştır. Bölgeler ve merkezi hükümet arasındaki fikir ayrılıkları dahası yasanın metropoliten kentleri tam olarak tanımlamaması, seçim sistemlerini ve yönetim yapısını belirlememesi, temel işlevlerini ortaya koymaması metropoliten kentlerin İtalya'da yeni bir yerel yönetim birimi olarak aktif hale gelmesini geciktirmiştir. 2001 yılında gerçekleşen bu anayasa değişikliği, bölge yönetimlerini güçlendiren hükümler içermekle beraber metropoliten kent biriminin önünü açan hükümler de içermektedir. Bunlara ek olarak yerel yönetimlerin güçlenmesi noktasında çok önemli olan finansal özerkleşmenin de önü bu anayasa değişikliği ile açılmıştır (Baldini ve Baldi, 2014:101). Bahsi geçen, finansal özerkleşme ya da alan yazınında bilinen haliyle mali federalizm 2009 yılında çıkarılan 42/2009 sayılı yasa ile hayata geçirilmiştir. Bu yasa mali federalizmin ilkelerini (yerel gelirler ve aynı yerel düzeyde mevcut finansal kaynaklar arasındaki denkleştirme; özerklik, sorumluluk, koordinasyon, uyum ve dayanışma) belirlemiştir (Bolgherini, 2014:201). 2014 yılına kadar farklı yasalarla bu yeni yerel yönetim birimi İtalyan yerel yönetim sistemi içinde işler hale getirilmeye çalışılmıştır. Ancak belediyeler, iller ve bölge yönetimlerinin konu üzerinde çeşitli çıkar çatışmalarından dolayı yasal düzenlemelerin pratikte uygulanamaması dahası metropoliten kentler ile diğer

16 Anayasa'nın ilk halinde 114. Madde “Cumhuriyet bölgelere, vilayetlere ve komünlere ayrılır” biçiminde iken, 2001 yılında anayasada yapılan değişiklikle madde belirtilen hale dönüşmüştür.

17 İtalyan Anayasasının 131. mddesine göre 20 bölge idaresi mevcuttur. 
yerel yönetim birimleri arasında oluşacak ilişki ve koordinasyon üzerinde bir türlü uzlaşılamaması metropoliten kent yönetimlerinin İtalya'da aktif hale gelmemesine sebep olmuştur (Boggero, 2016:4).

2014 yılında çıkarılan 56/2014 sayılı ve Delrio Yasası ${ }^{18}$ olarak bilinen düzenleme ile İtalyan merkezi hükümeti bölge yönetimlerini süreç dışında bırakarak Milan, Venedik ve Roma başta olmak üzere 10 şehirde metropoliten kent yönetimini kurmuştur. ${ }^{19}$ Bu yasa önceki girişimlerden farklı olarak kesin tanımlar ve merkezden işletilen bir prosedür sayesinde pratikte İtalyan yerel yönetim sisteminde çalışabilecek bir metropoliten kent yönetimini sisteme entegre etmiştir. Delrio yasasını da içine alan reform sürecinin perde arkasında 2008 yılında etkisini gösteren ekonomik kriz ve bu krizin şekillendirdiği siyasi atmosfer vardır. Yerel yönetimlerde hayata geçirmek istenen bir dizi reformun temel amacı aslında merkezi hükümetin krizle mücadele planının bir parçası olarak değerlendirilebilir. Delrio yasasını da kapsayan bu reformlar kamu harcamalarının kısılması ve siyasetin maliyetinin (temsil maliyeti) düşürülmesi amaçları etrafında toplanmıştır (Lippi, 2015: 12).

2014 yılında yürürlüğe giren ve 2015 yılında fiilen uygulanmaya başlayan Delrio yasası ile İtalyan yerel yönetim sisteminde yerini alan metropoliten kentler, arazi alanı ve demografik ve ekonomik ağırlık açısından heterojen bir niteliğe sahiptir. Örneğin, en büyük alanı kaplayan Metropolitan Kentler Turin $\left(6,827 \mathrm{~km}^{2}\right)$ ve Roma $\left(5,363 \mathrm{~km}^{2}\right)$ iken, diğer uçlarda Milan $\left(1,576 \mathrm{~km}^{2}\right)$, Cenova $\left(1,834 \mathrm{~km}^{2}\right)$ ve Napoli $\left(1,179 \mathrm{~km}^{2}\right)$ 'ye sahiptir. Torino ve Milano, sırasıyla, 42 ve Bari'nin 41'i ile karşılaştırıldığında 315 ve 134 belediyeyi kapsamaktadır. Üretilen zenginlik açısından, Milano, Roma ve Turin Katma Değer için en üst sırada yer almaktadır (https://www.ambrosetti.eu).

\section{TÜRKIYYE VE ITTALYA METROPOLITEN KENT YÖNETIMLERININ KARŞILAŞTIRILMASI}

1980’li yıllar İtalya ve Türkiye için yerel yönetim sisteminde reform çanlarının çaldığı bir dönem olarak kabul edilebilir. Her iki ülke de çağın değişen koşullarına bağlı olarak ortaya çıkan yeni problem ve ihtiyaçlara cevap verebilmek için metropoliten kent yönetimine ihtiyaç duymuştur. Türkiye İtalya ile karşılaştırıldığında görece daha erken bir tarihte büyükşehir belediyelerini sistemine dâhil ederek metropoliten kent yönetimiyle tanışmış olsa da ancak 2014 yılında uygulanmaya başlanan 6360 sayılı yasa ile metropoliten kent yönetimi uygulamasını yeni bir formda uygulamaya başlamıştır.

İtalya ise 25 yıl süren uzun uğraşlar sonucunda ancak 2014 yılında metropoliten kent yönetimine geçebilmiştir. Bu bağlamda bir değerlendirme yapıldığında metropoliten kentlerin kurulması sırasında ortaya çıkan problemler ülkelerin kendilerine özgü ve birbirinden farklı olsa da benzer ihtiyaçlara cevap vermek ve problemleri çözmek amacıyla geliştirilen bu uygulamaların karşılaştırılması metropoliten kent yönetimini anlamak için önemlidir. İki ülkenin de yapılan reform çalışmalarında optimal ölçekli yeni bir yerel yönetim organı aracılığıyla ekonomik kazanımlar amaçladığı söylenebilir. İki ülkenin motivasyonları benzer olsa da reformları hayata geçirme noktasında yaşanılan süreçler birbirinden tamamen farklıdır. Bölgeli ve iç kademeli bir yerel yönetim sistemine sahip İtalya, bölgeler ve merkezi hükümet arasındaki uzlaşı ve koordinasyon eksikliği yüzünden metropoliten alanlara özgü daha geniş ölçekli bir yerel yönetim modelini ancak 2014 yllından sonra uygulamaya koyabilmiştir.

\subsection{Görev ve Sorumluluklar}

İki ülkede metropoliten kent yönetimlerinin görev ve sorumlulukları incelenirken dikkat edilmesi gereken önemli hususlardan bir tanesi iki ülkenin yerelde yerine getirilmesi gereken hizmetlere yaklaşımlarındaki farklılıktır. İtalyan Anayasası'nın kamu hizmetlerinin yerine getirilmesinde vurguladığı ve geniş yer verdiği yerinden yönetim ilkeleri bu durumun en önemli göstergesidir. Özellikle son 20 yılda İtalya'da hayata geçirilen düzenlemelerle birçok kamu hizmeti bölge yönetimlerince veya yerel yönetimlerce yerine getirilmektedir. Türkiye'de ise birçok kamu hizmeti merkez tarafından doğrudan yerine getirilmektedir ya da hizmetlerin yerine getirilmesi noktasında merkezi hükümetin kontrolü söz konusudur. Aşağıdaki Tablo 1.’de karşılaştırmalı olarak

18 Yasanın tam adı, Metropoliten Kentler, İller, Birlikler ve Belediyelerin Birleşmeleri Hakkında Hükümler'dir. (Disposizioni sulle citta' metropolitane, sulle province, sulle unioni e fusioni di comuni), Yasa 07.04.2014 tarihli İtalyan Resmi Gazetesi'nde (Gazzetta Ufficiale) yayımlanmıştır. Yasa Bölgesel İşler ve Yerel Özerklik Bakanı Graziano Delrio'nun yoğun çabaları sonucu hayata geçtiği için onun adıyla anılmaktadır.

19 Bu kentler şunlardır: Turin, Milano, Venedik, Cenova, Bologna, Floransa, Roma, Bari, Napoli ve Reggio Calabria. Ancak ayrıca dört özel statülü kent vardır bunlar: Cagliari, Catania, Messina, Palermo kentleri de metropoliten kent statüsüne kavuşturulmuştur. Böylece toplam sayı 14'e çıkmıştır. 
iki ülkenin metropoliten alan yönetimlerinin başlıca görev ve sorumluluklarına yer verilmiştir. Bu tablo incelenirken yukarıda vurgulanan iki ülkenin yerel yönetim vizyonundaki farklılık dikkate alınmalıdır.

Tablo 1. Büyükşehir Belediyeleri ile Metropoliten Kentlerin Başlıca Görevleri

\begin{tabular}{|c|c|}
\hline İtalyan Metropoliten Kentleri & Büyükşehir Belediyeleri \\
\hline $\begin{array}{l}\text { - Yollar, trafik, } \\
\text { - Ulaşım ve planlama, } \\
\text { - Çevresel değerlerin korunması, } \\
\text { - Su elektrik hizmetleri, } \\
\text { - Sağlık hizmetleri (daha geniş alanlarda), } \\
\text { - Mesleki eğitim, okul hizmetleri } \\
\text { - Kentsel hizmetler, } \\
\text { - Ekonomik ve sosyal kalkınmanın } \\
\text { desteklenmesi ve koordinasyon } \\
\text { - Bilgi sistemleri ve dijitalleşme }\end{array}$ & $\begin{array}{l}\text { - İmar planlaması ve yapılaşma, } \\
\text { - Ruhsat vermek ve denetim, } \\
\text { - Ulaşım ve toplu taşıma hizmetleri, } \\
\text { - Coğrafi ve kent bilgi sistemleri, } \\
\text { - Yollar, meydan, vs. yapmak, } \\
\text { - Çevresel değerlerin korunması, } \\
\text { - Sağlik hizmetleri, } \\
\text { - Altyapı hizmetleri, } \\
\text { - Kentin kültürel, tabiat ve tarihi mirasının } \\
\text { - korunması, } \\
\text { - Su ve kanalizasyon hizmetleri, } \\
\text { - Terkezi 1sıtma hizmetleri, } \\
\text { - Tarım ve hayvancılığın geliştirilmesi. }\end{array}$ \\
\hline
\end{tabular}

Kaynak: Küçük, 2017'den yararlanılarak yazarlar tarafından hazırlanmıştır.

Türkiye'de merkezi yönetimin sorumluluğunda olan eğitim veya ağırlıklı olarak merkezi yönetim tarafindan yürütülen sosyal refah, sağlık hizmetleri, kültür ve spor gibi hizmetler, İtalya'da bölge ve yerel yönetim birimlerinin sorumluluğundadır (Küçük, 2017:18). Bu bağlamda bir değerlendirme yapıldığında benzer kentsel sorunları çözmek ve ihtiyaçlara cevap vermek için kurulmuş iki ülkedeki metropoliten kent yönetimlerinin görev ve sorumluluklarının birçok noktada benzeştiği görülmektedir.

Delrio yasası İtalya'da il yerel yönetim birimlerince yerine getirilen bütün yönetim fonksiyonlarının, belediye ve bölge yönetimleriyle uyum içerisinde olmak koşuluyla genel mekânsal ve stratejik planlamaların metropoliten kent yönetimlerince yerine getirilmesini öngörmektedir. Sosyal ekonomik gelişmeye yönelik politikalar üretmek, metropoliten alanlarda bilgi iletişim teknolojilerini geliştirmek ve bu konuda politikalar üretmek, karayolu ağı ile ilgili işler ve trafik düzenlemeleri, metropoliten alanlarda yaşayan vatandaşların kamusal çıkarlarıyla ilgili konularda politikalar üretmek metropoliten kent yönetimlerinin temel görev ve sorumlulukları olarak sayılabilir (Boggero, 2016:6). Bunlara ek olarak su ve elektrik hizmetleri, sağllk hizmetleri, mesleki eğitim ve okul hizmetleri, geriye kalan kentsel hizmetlerde İtalyan yerel yönetim sisteminde metropoliten kent alanlarında metropoliten kent yönetimlerince yerine getirilmektedir (Küçük, 2017:18).

Delrio yasası ve 2008 sonrası yapılan düzenlemelerin temel motivasyonunu kent için optimal bir bölgesel ölçek arayışıdır. Bu noktada yerel yönetim sisteminde hem örgütsel hem de işlevsel değişiklikler meydana gelmiştir (Bolgherini ve Lippi, 2016:283). Ölçek değişikliğinin arkasında yatan ekonomik sebepler İtalya ve Türkiye örneğinde benzerlik göstermektedir. İki örnekte de kent yönetiminde ölçek temelli bir değişiklikle işlevsel, örgütsel ve mali değişiklikler yoluyla kent mekanı ekonomik olarak daha elverişli hale getirilmeye çalışılmıştır.

\subsection{Organizasyon Yapısı}

Türkiye'de yerel yönetimlerin özerkliğine ilişkin Anayasa'da herhangi bir hüküm bulunmamaktadır. Ancak 5216 sayılı Büyükşehir Belediyesi Kanunu'nun 3. maddesinde büyükşehir belediyelerinin idari ve mali açıdan özerk olduğu açık bir biçimde ifade edilmektedir. Büyükşehir belediyelerinin organizasyonel yapısı ise 5215 sayılı Büyükşehir Belediyesi Kanunu'nun 3. maddesi ile 4. ve 5. bölümlerinde düzenlenmiştir. Kanunun 3. maddesinde büyükşehir belediyesinin organları: Büyükşehir belediye meclisi, büyükşehir belediye encümeni ve büyükşehir belediye başkanını olarak belirtilmiştir. 4. Bölümde bu organlara ilişkin hususlar; 5. Bölüm de ise, teşkilat yapısı ile personele dair hususlar düzenlenmiştir.

Kanunun 12. maddesine göre "Büyükşehir belediye meclisi, büyükşehir belediyesinin karar organıdır ve ilgili kanunda gösterilen esas ve usullere göre seçilen üyelerden oluşur". Burada 5216 sayılı Kanunun büyükşehir belediye meclisinin seçilme yöntemini açıkça belirtmediği görülmektedir. Büyükşehir Belediye Meclisi üyelerinin nasıl seçileceği 1984 yılında kabul edilen 2971 sayılı Mahalli İdareler İle Mahalle Muhtarlıkları ve Ihtiyar Heyetleri Seçimi Hakkında Kanun ile belirlenmiştir. Bu Kanuna göre büyükşehir belediye meclisi üyeliği için doğrudan seçim yapılmaz, ilçe belediye meclislerine seçilen üyelerden her ilçe belediye meclisi üyelerinin 
içinden en çok oy alan 1/5'i aynı zamanda büyükşehir belediye meclisi üyesi sıfatını elde eder ${ }^{20}$. Büyükşehir belediye yapısı içinde yer alan ilçe belediyelerinin belediye başkanları büyükşehir belediye meclisinin doğal üyesidir ${ }^{21}$.

Büyükşehir belediye encümeni bazı görevleri itibariyle yürütme organı, bazı görevleri itibariyle de karar organı işlevine sahiptir. 5216 sayılı Kanunun 16. maddesine göre; büyükşehir belediye encümeni, belediye başkanının başkanlığında, belediye meclisinin kendi üyeleri arasından bir yıl için gizli oyla seçeceği beş üye ile biri genel sekreter, biri malî hizmetler birim amiri olmak üzere belediye başkanının her yıl birim amirleri arasından seçeceği beş üyeden oluşur.

Büyükşehir belediye başkanı, büyükşehir belediyesinin yürütme organdır. 5216 sayılı Kanunun 17. maddesine göre; büyükşehir belediye başkanı, büyükşehir belediye idaresinin başı ve tüzel kişiliğinin temsilcisidir. Büyükşehir belediye başkanı seçimle iş başına gelir ve büyükşehir belediyesi sınırları içindeki seçmenler tarafından doğrudan seçilir. Büyükşsehir belediyelerinin idari teşkilatı 5216 sayılı Kanunun 21. maddesinde düzenlenmiştir. Anılan maddeye göre;

"büyükşehir belediyesi teşkilâtı; norm kadro esaslarına uygun olarak genel sekreterlik, daire başkanlıkları ve müdürlüklerden oluşur. Birimlerin kurulması, kaldırılması veya birleştirilmesi büyükşehir belediyesi meclisinin kararı ile olur. Büyükșehir belediyesinde başkan yardımcısı bulunmaz. Hizmetlerin etkili ve verimli bir şekilde yürütülebilmesi için, genel sekretere yardımcı olmak üzere, norm kadroya uygun olarak genel sekreter yardımcisı atanabilir".

$\mathrm{Bu}$ düzenlemeye bakıldığında büyükşehir belediyelerinin teşkilatlanması için şunlar söylenebilir:

- Büyükşehir belediyelerinin iç örgütlenmesinin biçimi (hiyerarşik seviyeleri) Kanun tarafindan tanımlanmış, ancak birimler belirlenmemiştir. $\mathrm{Bu}$ doğrultuda organizasyonel yapı içinde daire başkanlıkları ve şube müdürlükleri biçiminde bir yapılanma öngörülmüştür. Dolayısıyla iki kademeli bir teşkilatlanma söz konusudur.

- Teşkilat yapısı içinde hangi daire başkanlıklarının kurulacağı belirtilmemiş, bu konudaki yetki büyükşehir belediye meclisine verilmiştir ${ }^{22}$. Böylece iç örgütlenmede esneklik sağlanmıştır ${ }^{23-24}$.

İtalya'da metropoliten kentlerin özerk olduğu Anayasanın 114. maddesinde açıkça belirtilmektedirr ${ }^{25}$. Başlangıçta metropol kent yönetiminin organları için özel bir düzenleme yapılıncaya kadar il yönetimine ilişkin kuralların uygulanması kabul edilmiştir (Geray, 1997:62). İtalyan metropoliten kentlerinin yönetim organları Türkiye'deki büyükşehir belediyeleri ile benzeşmektedir. Burada da metropol kent meclisi, metropol encümeni (Guinta) ve metropol belediye başkanı bulunmaktadır. Metropol kent meclisi ve başkanı seçimle, encümen (Guinta) ise atamayla iş başına gelmektedir (Geray, 217:65). Metropoliten kent başkanları belediye meclisleri tarafından seçilir. Belediye meclisleri halk tarafından seçilir ve görev süresi 5 yıldır (www.ponmetro.it). Ancak daha sonra 2014 tarihli Delrio Yasası bazı değişiklikler getirmiştir. Buna göre metropoliten kent yönetiminin idari işlerinden sorumlu yapı yani metropoliten konsey üyeleri halk tarafindan değil başkan ve metropoliten kent

202971 sayı11 Kanunun 6. maddesine göre; büyük şehir belediye meclisleri belediye hudutları içinde kalan ilçe seçim çevreleri için tespit edilen belediye meclisleri üye sayısının her ilçe için beşte biri alınmak suretiyle bulunacak toplam sayı kadar üyeden teşekkül eder. 24. Maddesine göre de; Bu Kanunun 6 nc1 maddesinde tespit olunan büyük şehir meclisi üyeleri, her ilçe ve ilk kademe belediyesi için seçilmiş olan asıl üyelerin seçiliş sıralarına göre baştan başlayarak yeter sayıya kadar inilmek suretiyle bulunur.

215216 sayılı Kanunun 12. maddesine göre Büyükşehir belediye başkanı büyükşehir belediye meclisinin başkanı olup, büyükşehir içindeki diğer belediyelerin başkanları, büyükşehir belediye meclisinin doğal üyesidir.

225393 sayılı Belediye Kanunu'un 48. maddesinde "Belediye teşkilâtı, norm kadroya uygun olarak yazı işleri, malî hizmetler, fen işleri ve zabıta birimlerinden oluşur. Beldenin nüfusu, fizikî ve coğrafí yapısı, ekonomik, sosyal ve kültürel özellikleri ile gelişme potansiyeli dikkate alınarak, norm kadro ilke ve standartlarına uygun olarak gerektiğinde sağllk, itfaiye, imar, insan kaynaklarl, hukuk işleri ve ihtiyaca göre diğer birimler olușturulabilir. Bu birimlerin kurulması, kaldırılması veya birleștirilmesi belediye meclisinin kararıyla olur" denilmektedir. 3593 sayılı Kanuna tabi belediyeler açısından her belediye teşkilatı içinde dört birimin kurulması zorunluluğu öngörülmüş, bunların dışında yeni birim kurma yetkisi belediye meclisine verilmiştir. Ancak kanunda "norm kadroya" vurgu yapılması, dolaylı olarak iç birim oluşturmada doğal sınırı oluşturmaktadır.

23 Avrupa Yerel Yönetimler Özerklik Şartının 6. Maddesinin 1. paragrafında "Kanunla düzenlenmiş daha genel hükümlere halel getirmemek koşuluyla, yerel makamlar kendi iç idari örgütlenmelerini, bunları yerel ihtiyaçlarla uyumlu kılmak ve etkin idare sağlamak amactyla, kendileri kararlaştırabileceklerdir”, denilmektedir. Türkiye bu paragrafa çekince koymakla birlikte, 5216 sayı1lı Kanundaki düzenlemenin Avrupa Yerel Yönetimler Özerklik Şartına uygun olduğu görülmektedir.

24 Türkiye'de gerçekleşen yerel yönetim reformlarının Avrupa Yerel Yönetimler Özerklik Şartı'na konulan çekinceleri anlamsız kıldığı yönünde görüşler mevcuttur (Ekşi ve Coşkun, 2013:13). Detaylı bilgiye "Avrupa Yerel Yönetimler Özerklik Şartı ve Ek Protokol Bağlamında Türkiye'deki Yerel Yönetim Sisteminin Değerlendirilmesi" adlı bildiriden ulaşılabilir.

25 Avrupa Yerel Yönetimler Özerklik Şartının 2. maddesinin 1. paragrafında "Özerk yerel yönetimler ilkesi ulusal mevzuatla ve uygun olduğu durumlarda anayasa ile tanınacaktır”, denilmektedir. Türkiye yerel yönetimlerin özerkliğini kanunla, İtalya ise anayasa ile tanımıştır. 
yönetiminin idari sınırları içerisinde bulunan belediye konseyi üyeleri tarafından seçilir. Başkanın seçilmesine ilişkin düzenlemeler ise kesin olarak belirlenmemiş farklı kentlerde doğrudan seçim gibi farklı uygulamalar mevcuttur (Boggero, 2016:9).

Doğrudan seçim yasada bir alternatif olarak yer almış ama seçim usullerine ilişkin düzenlemeler metropoliten kent yönetimine bırakılmıştır. Eğer metropoliten kent yönetimi doğrudan seçim üzerinde uzlaşırsa bu durum İtalyan parlamentosu tarafindan bir yasa ile onaylanmalıdır.

Metropoliten kent yönetiminin idari teşkilatının oluşturulması ve bunun iç örgütlenmesi konusunda Türkiye'de olduğu gibi, kent yönetimine bir serbestlik tanındığı görülmektedir. Dolayısıyla ihtiyaca dayalı bir teşkilatlanmaya gitme yöntemi benimsenmiştir. Venedik metropoliten kent yönetimi örneği değerlendirildiğinde, Venedik metropoliten kent yönetiminin organizasyon yapısı 2015 y1lından itibaren oluşmaya başladığı görülmektedir. Delrio yasası ve 1990 sonrası yapılan yasal düzenlemelerin öngördügüü üzere yapının oluşturulması yerel karar alma mekanizmalarına bırakılmıştır (OECD, 2015:14) ${ }^{26}$. Bölgelerin yerel yönetim sistemindeki ağırlığı ve metropoliten kentlere ilişkin yapıcı olamayan tavırları sebebiyle İtalya'da metropoliten kent yönetimleri örgütlenmelerine ilişkin süreç yavaş ilerlemiştir. Türkiye'de ise merkezi hükümetin etki alanının İtalya'ya kıyasla daha geniş olması sebebiyle 2014 sonrası süreç hızlı ilerlemiş ve yeni büyükşehir beledileri idari örgütlenmelerini büyük ölçüde tamamlamışlardır.

\subsection{Mali Yapı}

İtalya ve Türkiye'nin yerel yönetim birimlerinin mali yapıları ülkelerin devlet örgütlenmesinin farklı olmasından dolayı birbirinden farklılaşmaktadır. İtalya'da bölge yönetimlerinin varlığı ve yerel yönetimlerinin Türkiye'ye göre daha özerk bir yapılarının olması bu farklılığın temel sebebi olarak belirtilebilir. Ancak yine de bir karşılaştırma yapabilmek için her iki ülkedeki temel mali yapıyı ele almakta yarar vardır.

Türkiye'de yerel yönetimlerin mali yapısı ile ilgili olarak Anayasa'nın 127. maddesinde yerel yönetimlere "görevleri ile orantılı gelir kaynakları sağlanır" denilmekte, bu ilke doğrultusunda gelirlerin merkezi yönetimle yerel yönetimler arasında bölüşülme yöntemini kanun koyucunun takdirine bırakmaktadır. Türkiye'de belediyelerin yeni vergi oluşturma veya var olan bir vergiye oran ilave etme yetkisi bulunmamaktadır.

6360 sayılı Kanun büyükşsehir belediye sistemin için getirdiği yenilikler yanında, merkezi yönetimle yerel yönetimler arasındaki gelir bölüşümünü de yeniden düzenlemiştir. Bu kapsamda büyükşehir belediyesine sınırları içinde toplanan vergilerden ve ilçe belediyesine genel bütçe gelirlerinden aktarılan miktardan pay verilmektedir. Kanunun 25. maddesine göre; 06.06.2002 tarihli ve 4760 sayılı Özel Tüketim Vergisi Kanununa ekli (I) sayılı listede yer alan mallardan tahsil edilen özel tüketim vergisi hariç olmak üzere, büyükşehir belediye sınırları içinde yapılan genel bütçe vergi gelirleri tahsilâtı toplamının yüzde 6'sı ile genel bütçe vergi gelirleri tahsilâtı toplamı üzerinden büyükşehirlerdeki ilçe belediyelerine ayrılan payların yüzde 30'u büyükşehir belediye payı olarak ayrılır. Bu gelirler büyükşehir belediyesinin en önemli gelirlerini oluşturmaktadır. 1948 İtalyan Anayasası ise, 119. maddede;

"Komünler, iller, metropol kentler ve bölgeler gelir ve harcama özerkliğine sahiptir. Komünler, iller, metropol kentler ve bölgeler bağımsız mali kaynaklara sahip olur. Anayasaya uygun olarak ve devlet maliyesinin koordinasyon ve vergi sisteminin prensiplerine göre vergi koyabilir ve kendi gelirlerini toplayabilirler. Kendi topraklart ile ilgili vergi gelirlerinden pay alırlar",

denilmektedir. Görüldüğü gibi anayasa yerel yönetimlere hem gelir ve harcama özerkliği hem de vergi koyma yetkisi vermektedir. Bunların yanında yerel yönetimlere tahsis edilen gelirler için ifade edilen "kendilerine atfedilen kamusal fonksiyonların tam olarak finanse etmeyi sağlama" yaklaşımı da bizim Anayasamızda yer alan mali tevzin (akçal dengeleme) ilkesine göre daha güçlü bir düzenleme olarak nitelendirilebilir.

İfade edilen anayasal ilkeler yanında uygulamaya bakıldığında; İtalyan merkezi hükümeti temel olarak gelir vergilerini toplayıp bunların farklı kademelere dağıtılmasından sorumlu iken bölge yönetimleri bazı küçük vergilerle beraber akaryakıt vergilerini toplayıp bu mali kaynağı yönetmekle yükümlüdür. Metropoliten kent yönetimlerinin gelir kaynakları ülke genelinde her bölge için farklı olmakla beraber genel prensip gelirlerin İtalyan merkezi hükümetinden aktarılan kaynaklardan oluştuğu yönündedir. Belediyeler merkezi hükümet ve bölge yönetiminden aktarılan kaynakların yanı sıra mülkiyet vergisi ve kendine has yerel kaynaklara da sahiptir (Toniolo ve Pugliese, 2003:252).

26 İtalya Avrupa Yerel Yönetimler Özerklik Şartını herhangi bir çekince koymadan imzalamıştır. İç örgütlenmeye ilişkin Şartın düzenlemesine daha önce değinilmişti. 
Genel olarak, İtalya'da bulunan yerel yönetim birimlerinin temel gelir kaynakları temel olarak vergilerden, merkezi hükümet tarafından sağlanan fonlardan ve vatandaşların harcamalarından elde edilen gelirlerden oluşur. $\mathrm{Bu}$ gelirler yerel yönetim birimlerinin toplam bütçelerinin \%87'sini oluşturur (Bohlooli Zamani ve Dessì, 2019:72). Yukarıda belirtilen kaynaklardan toplanan gelirler, komünler, iller, metropol kentleri ve bölgelerin, kendilerine atfedilen kamusal fonksiyonları tam olarak finanse etmelerini sağlar.

İtalya'da 2007 sonrası yasal düzenlemeler ile hayata geçirilen ve hala uygulama düzeyinde hayata geçirilme noktasında sıkıntılar olan reformların en önemli hazırlayıcılarından bir tanesinin kamu mali disiplini sağlamak olduğunu hatırlatmakta yarar vardır. Yapılan bu düzenlemeler bütçede kesintiler ve kamu harcamalarında küçülme öngörmektedir. Düzenlemelerin yansımalarına bakıldığında, belediye hizmetlerinde küçülmeler, yerel vergilerin artması ve yerel yönetim organları arasında yerel bütçe çekişmelerinin gün yüzüne çıkması gibi yansımalar reform çalışmalarının dolaylı sonuçları olarak okunabilir. Tüm bu süreçte hiç kuşkusuz 2008 ekonomik krizi önemli bir belirleyici olarak karşımıza çıkmaktadır (Bolgherini, 2014:209).

\section{SONUÇ}

Dünya genelindeki nüfus artışı ve sanayi devrimi sonrası şartların etkisiyle, kentlerin nüfusu artmış ve mekânsal sınırlarında önemli miktarda bir genişleme gerçekleşmiş, böylece metropoliten kentler ortaya çıkmıştır. Metropoliten kentlerin ulus devlet sonrası oluşan kentin geleneksel idari kurumlarıyla yönetilmesinde zorluklar yaşanmış, buda yeni arayışları beraberinde getirmiştir. Bu arayışların sonucunda 20. yüzyıl içerisinde muhtelif ülkelerde birçok metropoliten kent yönetimi örneği ortaya çıkmıştır.

Metropoliten kent yönetimlerinin temel görevleri olarak, verimlilik ve etkinlik açısından metropoliten alanda koordinasyonu veya tek elden yönetimi gerektiren mekansal planlama, toplu taşıma, karayolu ve ray sistemleri, atık yönetimi ve atık-su yönetimi ön plana çıkmıştır. Bazı uzmanlar ayrıca, sosyal yardım, sağlık hizmetleri ve eğitimi de bu kapsama dahil etmektedir. Yakın zamanlarda da metropoliten kent yönetimi ile ilgili tartışmaların odağı, belli kentsel hizmetlerin koordinasyonundan, bölgenin ekonomik kalkınma ve rekabetçiliğini içerecek şekilde genişlemiştir (Swianiewicz ve Lackowska-Madurowicz, 2012:2-3).

Türkiye'de metropoliten kent yönetimine ilişkin tartışmalarının İtalya'ya kıyasla daha erken somut sonuç doğurduğu görülmektedir. Türkiye'de metropoliten kent yönetimine ilişkin anayasal zemin 1982 Anayasasıyla oluşturulmasına karşın, İtalya'da metropoliten kent yönetimi 2001 yılında anayasaya dahil edilmiştir. Ancak genel olarak yerel yönetimler, İtalyan Anayasasında daha güçlü ve detaylı olarak düzenlendiğinden, bizim anayasamızdaki "kanun, büyük yerleşim merkezleri için özel yönetim biçimleri getirebilir" biçimindeki düzenleme, İtalyan Anayasasına göre genel kalmaktadır. Çünkü İtalyan Anayasasında açıkça "metropol kentlerden" söz edilmekte (m. 114) ve özerklikleri vurgulanmaktadır. Buna karşın Türkiye'de ilk büyükşehir belediyesi 1984 yılında oluşturulup faaliyete geçirilmiş, İtalya'da metropoliten kent yönetimine ilişkin ilk yasal düzenleme 1990 yılında yapılmıştır. Ancak oluşturulan bu metropol kent yönetimlerinin aktif hale gelmesi 2014 yılını bulmuştur. 2014 yılı Türkiye için de önemli bir yıldır. Çünkü 2012 yılında 6360 sayılı Kanun ile değiştirilen ve coğrafi sınırlar yönünden il yönetimi esas alınarak yaygınlaştırılan yeni büyükşehir belediye sistemi tam olarak 2014 yerel seçimleri ile birlikte hayata geçmiştir.

İtalya ve Türkiye'de metropoliten kent yönetimleri ve büyükşehir belediyeleri karş1laştırılırken dikkati çeken diğer bir konu, iki ülkenin Avrupa Yerel Yönetimler Özerklik Şartı karşısındaki tutumudur. Türkiye ülkedeki sosyal, siyasi ve ekonomik koşullar sebebiyle Avrupa Yerel Yönetimler Özerklik Şartı'na ihtiyatla yaklaşmış ve Şartın bazı düzenlemelerine çekince koymuştur. Bun karşılık İtalya'nın çekince koyduğu Şartın herhangi bir maddesi bulunmamaktadır. Bundan dolayı İtalya, Türkiye'ye göre daha özerk yerel yönetimlere sahip bir ülkedir.

Büyükşehir belediyeleri ile metropoliten kent yönetimleri yönetim organları ve organizasyonel yapı açısından karşılaştırıldığında arada büyük farkların olmadığı görülmektedir. Büyükşsehir belediyelerinin üçlü organ yapısının bir benzerine İtalyan metropoliten kent yönetimleri de sahiptir. İdari teşkilat açısından da iç örgütlenme serbestliğinin her iki modelde de tanındığı görülmektedir.

Mali yapı açısından İtalyan Anayasasının içerdiği düzenlemelerden dolayı, metropoliten kent yönetimlerinin büyükşehir belediyelerine kıyasla daha avantajlı olduğu söylenebilir. Çünkü İtalya'da anayasa yerel yönetimlere vergi ihdas etme yetkisi vermektedir. Aynı zamanda "gelir ve harcama özerkliğini”" de anayasa vurgulamaktadır.

Son olarak her iki modelde de mekansal planlama, toplu taşıma, karayolu ve ray sistemleri, atık yönetimi ve atık-su yönetimi gibi görevler ön plana çıkmaktadır. Ancak İtalyan metropoliten kent yönetimleri açısından, 
ekonomik kalkınma ve kentin ulusal ve uluslararası düzeyde rekabet kapasitesini geliştirme yönündeki rekabetçi kapasitesini geliştirme yaklaşımı da söz konusudur.

\section{KAYNAKÇA}

BALDINI, Gianfranco ve BALDI, Brunetta (2014), "Decentralization in Italy And The Troubles of Federalization", Regional \& Federal Studies, S.24(1), ss.87-108.

BOGGERO, Giovanni (2016), "The Establishment of Metropolitan Cities in Italy: An Advance or a Setback for Italian Regionalism?", Perspectives on Federalism, S.8(3), ss.1-22.

BOLGHERINI, Silvia (2014), “Can Austerity Lead to Recentralisation? Italian Local Government During The Economic Crisis", South European Society and Politics, S.19(2), ss.193-214.

BOLGHERINI, Silvia ve LIPPI, Andrea (2016), "Remapping Local Government from Re-Allocation And ReShaping to Re-Scaling", Theoretical Foundations and Discussions on the Reformation Process in Local Governments (Ed.Uğur Sadioğlu, Kadir Dede), IGI Global, Pensilvanya - US, ss.266-288.

DEMIR, Kemal ve ÇABUK, Suat (2010), "Türkiye'de Metropoliten Kentlerin Nüfus Gelişimi", Erciyes Üniversitesi Sosyal Bilimler Enstitüsü Dergisi, S.28(1), ss.193-215.

DPT (1977), "4. Beş Yıllık Kalkınma Planı", Yerleşme, Bölgesel Gelişme, Kentleşme, Konut Özel İhtisas Komisyonu Raporu, DPT Yayını, Ankara.

DPT (1979), Dördüncü Beş Yılık Kalkınma Planı (1979-1983), DPT Yayını, Ankara.

ÇINAR, Tayfun, ÇINER, Umut Can ve ZENGINN, Ozan (2009), Büyükşehir Yönetimi Bütünleştirme Süreci, TODAIIE Yayını, Ankara.

EKE, Ali Erkan (1982), Anakent Yönetimi ve Yönetimlerarası İlişkiler, Ankara Üniversitesi SBF Yayınları, Ankara.

EKE, Ali Erkan (1985), "Anakent Yönetimi ve Yönetimlerarası İlişkiler: Batı Deneyimi ve Türkiye", Amme İdaresi Dergisi, S.18(4), ss.41-68.

ERGINAY, Akif (1951), "İtalya Cumhuriyeti Anayasası", Ankara Üniversitesi Hukuk Fakültesi Dergisi, S.8(1), ss.778-805, http://dergiler.ankara.edu.tr/dergiler/38/275/2915.pdf (Erişim Tarihi: 19.08.2018).

EŞKİ ÇAYLAK, Şeyma ve COŞKUN, Bayram (2013), "Avrupa Yerel Yönetimler Özerklik Şartı ve Ek Protokol Bağlaminda Türkiye'deki Yerel Yönetim Sisteminin Değerlendirilmesi", Kamu Yönetimi Sempozyumu (KAYSEM) Bildiriler Kitabı, 11-12 Mayıs 2013, Mustafa Kemal Üniversitesi Yayını, Hatay.

GERAY, Cevat (1997), "İtalya'da Yerel Yönetimler", Çağdaş Yerel Yönetimler Dergisi, S.6(1), ss.53-76.

GÜL, Hüseyin ve BATMAN, Seda (2013), "Dünya ve Türkiye Örneklerinde Metropoliten Alan Yönetim Modelleri ve 6360 Sayll Yasa", Yerel Politikalar Dergisi, S.3, ss.7-47.

HOUT, Jean-Louisn (2000), Dünyanın İlk Kentleri, Kentlerin Doğuşu (Çev. Ali Bektaş Girgin), İmge Kİtabevi, Ankara.

İCI, Ferit ve TURAN, Menaf (2013), "Türkiye'de Büyükşehir Belediyesi Sistemi ve 6360 Sayılı Yasa ile Büyükş̧ehir Belediyesi sisteminde Meydana Gelen Değiş̧imler: Van Örneği", Süleyman Demirel Üniversitesi İktisadi ve İdari Bilimler Fakültesi Dergisi, S.18(1), ss.117-152.

KÜÇÜK, Hülya (2017), “Ittalya ve Türkiye'de Yerel Özerklik:Karşılaştırmalı Bir Değerlendirme”, Yüzüncü Yıl Üniversitesi Sosyal Bilimler Enstitüsü Dergisi, S.1(4), ss.932-953.

LEFEVRE, Christian (1998), "Metropolitan Government and Governance in Western Countries: A Critical Review”, International Journal of Urban and Regional Research, S.22(1), ss.9-25.

LIPPI, Andrea (2015), "'A Laboratory For The Disorder?' Never-Ending De-Centering And Re-Centering in Intergovernmental Relations in The Italian Case", International Conference on Public Policy, 1-4 July 2015 - Milan, ss.1-24. 
MEHTAP - MERKEZî HÜKÜMET TEŞKİLÂTI ARAŞTIRMA PROJESİ (1966), Merkezî Hükümet Teşkilâtı Araştırma Projesi Yönetim Kurulu Raporu, Türkiye ve Orta Doğu Amme İdaresi Enstitüsü Yayınları, Ankara.

MERİ̧, Osman (1983), Anayasalarda Mahallî İdarelerle İlgili İlkeler ve İdarî Vesayet, Prof. Fehmi Yavuz'a Armağan, Ankara Üniversitesi Siyasal Bilgiler Fakültesi Yayınları, Ankara.

MUMFORD, Levis (2013), Tarih Boyunca Kent (Çev. Gürol Koca, Tamer Tosun), Ayrıntı Yayınları, İstanbul.

OECD (2015), Governing The Metropolitan City of Venice, OECD Publishing, Paris, https://read.oecdilibrary.org/urban-rural-and-regional-development/governing-the-metropolitan-city-ofvenice_9789264223592-en\#page1 (Erişim Tarihi: 08.08.2018).

OKTAY, Tarkan (2016), "Metropol Kent Yönetimi Yaklaşımları ve Uygulama Modelleri”, Strategic Public Management Journal, S.2(4)., ss.49-71.

ÖZGÜR, Hüseyin ve SAVAŞ YAVUZÇEHRE, Pınar (2016), “Türkiye’nin Büyükşehir Belediyesi Sistemi: 1982-2015”, Çankırı Karatekin Üniversitesi Sosyal Bilimler Enstitüsü Dergisi, S.7(1), ss.903-926.

SWIANIEWICZ, Paweł ve LACKOWSKA-MADUROWICZ, Marta (2012), Avrupa'da İki Kademeli Büyükşehir Belediyesi Düzenlemeleri Tuselog Programı için bir Literatür Araştırması, Türk İsveç Yerel Yönetimler Ortaklığı Programı Yayını.

TOKSÖZ, Fikret, ÖZGÜR, Ali Ercan, ULUÇAY, Öykü, KOÇ, Levent, ATAR, Gülay ve AKALIN, Nilüfer (2009), Yerel Yönetim Sistemleri Türkiye ve Fransa, İspanya, İtalya, Polonya, Çek Cumhuriyeti, TESEV Yayınları, İstanbul.

TONIOLO, Mariolina ve PUGLIESE, Turiddo (2003), "Metropolitan Development in Venice: Ordinary Trends in An Extraordinary City", Metropolitan Governance And Spatial Planning (Ed. Willem Salet, Andy Thornley, Anton Kreukels), Spon Press, Londra ve New York, ss.244-263.

TOPRAK, Zerrin (2014), Yerel Yönetimler, Siyasal Kitabevi, Ankara.

TORTOP, Nuri (1996), “Italya'da Yerel Yönetimlerin Yapısı ve Son Düzenlemeler”, Çağdaş Yerel Yönetimler Dergisi, S.3(5), ss.63-70.

YILMAZ, Cevdet (2013), “Dünya Nüfusunun Tarihsel Gelişim Seyri ve Günümüzde Ulaştı̆̆ı Boyut”, Dernekler Dergisi, S.23, ss.40-43.

YILMAZ, Vedat ve KAYPAK, Şafak (2019), "6360 Sayılı Yasa Sonrası Yeni Büyükşehir Belediyelerindeki Çevre Sorunlarının Irdelenmesi", Kent Akademisi Dergisi, S.12(1), ss.1-28.

ZAMANI, Mahsa Bohlooli ve DESSI, Silvia (2019), "Local Governments' Approach towards Green Bond", Master Thesis, Politecnico Di Milano School of Architecture, Milano - Italy, https://www.politesi.polimi.it/bitstream/10589/147548/1/2019_04_Bohlooli\%20Zamani_Dessì.p df (Erişim Tarihi: 28.07.2019).

ZENGiN, Ozan (2014), “Büyükşehir Belediyesi Sisteminin Dönüşümü:Son On Yılın Değerlendirmesi”, Ankara Barosu Dergisi, S.2014(2), ss.91-117.

http://www.adalet.gov.tr/duyurular/2011/eylul/anayasalar/ulkeana/pdf/10-İTALYA\%20319-354.pdf～(Erişim Tarihi: 13.08.2018).

http://www.ponmetro.it/wp-content/uploads/2016/10/LEGGE_7-04-2014_n-56.pdf (Erişim Tarihi: 19.08.2018).

https://www.ambrosetti.eu/en/whats-hot-en/cities-and-territories/collaboration-between-metropolitancities-and-non-metropolitan-areas/ (Erişim Tarihi: 18.08.2018).

tbb.gov.tr/mevzuat/kanunlar/Avrupa_Yerel_Yonetimler_ozerklik_Sarti.pdf (Erişim Tarihi: 17.08.2018). 